\title{
Bifidobacterium from infant stool: the diversity and potential screening
}

\author{
DYAH FITRI KUSHARYATI ${ }^{1, \bullet}$, HENDRO PRAMONO ${ }^{1}$, DINI RYANDINI ${ }^{1}$, TSANI ABU MANSHUR ${ }^{1}$, \\ MEILANY ARIATI DEWI ${ }^{1}$, KHUSNUL KHATIMAH ${ }^{1}$, ANWAR ROVIK ${ }^{2}$ \\ ${ }^{1}$ Department of Microbiology, Faculty of Biology, Universitas Jenderal Soedirman. Jl. Suparno No. 63, Grendeng, Purwokerto, Banyumas 53122, Central \\ Java, Indonesia. Tel.: +62-281-638794, Fax.: +62-281-631700, `email: dfitri.k@gmail.com. \\ ${ }^{2}$ Centre for Tropical Medicine, Faculty of Medicine, Public Health, and Nursing, Universitas Gadjah Mada. PAU Building $2^{\text {nd }}$ Floor. Jl. Teknika Utara, \\ Sleman 53288, Yogyakarta, Indonesia
}

Manuscript received: 21 April 2020. Revision accepted: 13 May 2020

\begin{abstract}
Kusharyati DF, Pramono H, Ryandini D, Manshur TA, Dewi MA, Khatimah K, Rovik A. 2020. Bifidobacterium from infant stool: the diversity and potential screening. Biodiversitas 21: 2506-2513. Bifidobacteria spp. are a group of Lactic Acid Bacteria commonly found in the gastrointestinal tract of adults and infants. LAB are known as probiotics and have many health benefits. This research aimed to isolate Bifidobacteria from infant stool, identify, explore their diversity, and screen their potential as probiotics. Stool samples were collected from 3 healthy infants in Banyumas Regency. The potential screening included lysozyme resistance, antimicrobial activity, and exopolysaccharide production. A total of 7 Bifidobacterium species were isolated from infant stool: $B$. catenulatum, B. minimum, B. indicum, B. dentium, B. asteroides, B. galicum, and B. coerinum. B. indicum isolates $(\mathrm{Bb} 3 \mathrm{~F}$ and $\mathrm{Bb} 1 \mathrm{~B})$ had the greatest inhibition activity against Escherichia coli and Candida albicans with 10.80 and 9.70 mm, respectively. Bifidobacteria isolates were resistant to lysozyme from egg whites up to $200 \mu \mathrm{g} \cdot \mathrm{mL}^{-1}$. B. catenulatum Bb1A isolate had the highest yield of exopolysaccharide production with $74 \mathrm{mg} . \mathrm{L}^{-1}$. Among them, three Bifidobacterium strains (Bb1B, Bb2A, and Bb2E) were considered potentially as probiotics.
\end{abstract}

Keywords: Bifidobacterium, diversity, exopolysaccharide, infant stool, microbes

\section{INTRODUCTION}

The human digestive tract contains many niches of microbial ecosystems. Microbes can grow and colonize certain parts of the human digestive system. These microbial groups are estimated to reach as many as 400 500 species which vary according to the location of the intestinal tract (Ramakrishna, 2013). Lactic acid bacteria (LAB) and Bifidobacteria naturally form dynamic ecosystems in the human digestive tract. The main LAB found in the human intestines consists of Lactobacillus and Leuconostoc. Meanwhile, Bifidobacterium is dominant among the first invaders of newborns, a month after birth (Sirilun et al., 2015).

Bifidobacterium is commonly found in the vagina and the human digestive tract (Attri et al., 2018) as well as newborn digestive tracts (Penders et al., 2006). Bacterial colonization in the digestive tract begins during birth due to the infant contact to the vaginal tract and fecal microbiota (Palmer et al., 2007). LAB and Bifidobacteria are acquired from the environment of which ingested food is presumably the main source. The group of bacteria that dominates the intestines in adult individuals is $\mathrm{LAB}$, including Lactobacillus, Bifidobacterium, and Bacteroides (Attri et al., 2018).

Bifidobacterium is a LAB that can be potentially used as a probiotic. Probiotics are a group of living bacteria that provide beneficial health effects when consumed in sufficient quantities (Bermudez-Brito et al., 2012). Bifidobacterium may help to establish the mucosal barrier, produce beneficial metabolites, develop the immune system, and prevent the pathogenic colonization (Liu et al., 2016; Yan et al., 2017). Bifidobacterium produces bacteriocin that expresses an inhibition to some bacteria from different genera, such as Arcobacter butzleri, Brochothrix thermosphacta, C. difficile, H. pylori, $L$. monocytogenes, S. aureus, and S. typhimurium (Martinz et al., 2013).

Information about human microbes can be obtained by analyzing the microbial content in stool samples. Subijanto and Reza (2006) stated that the titer of Bifidobacterium and Enterococcus from breast-milk-feed infants are $10^{10}-10^{11}$ CFU.g ${ }^{-1}$ and $10^{8}$ CFU. ${ }^{-1}$, respectively, as well as other anaerobic bacteria. Palmer et al. (2007) stated that the infant digestive tract contains a diverse and dynamic pattern of microbial composition. Therefore, infant stool is an appropriate source to explore the diversity of Bifidobacteria. The exploration of Bifidobacterium species from feces samples was considered important. Recently, research has focused on identifying new strains of Bifidobacterium and their safety confirmation (Hadadji et al., 2005; Hendrati et al., 2017; Rada et al., 2010; Zidene \& Faid, 2007). This research aimed to isolate Bifidobacteria from infant stool, identify, explore the diversity, and screen their potential use as probiotics. 


\section{MATERIALS AND METHODS}

\section{Isolation}

The stool samples were collected from 3 healthy infants (less than one month-aged) in Banyumas Regency: Banyumas, Sokaraja, and Purbalingga District. Stool samples were collected in a sterile container and directly transported to the laboratory, then stored at $-20^{\circ} \mathrm{C}$. Upon experiment, a gram of stool samples was diluted up to $10^{-5}$ using sterile-distilled water. The last two dilutions were surface-plate cultured on deMann Rogosa and Sharpe Agar (MRSA) medium (Oxoid) and incubated at $37^{\circ} \mathrm{C}$ for 4 days under anaerobic condition. Colonies that appeared as smooth, white, and round colonies were considered as Bifidobacteria. A total of 22 colonies from the highest dilution of 3 different samples were picked up, randomly. Selected colonies were then re-cultured on the MRSA medium to obtain pure cultures.

\section{Colony characterization}

The colony morphology of purified culture on the MRSA medium was studied after 24 hours of incubation, such as their size, elevation, shape, and color.

\section{Cellular characterization}

Gram's staining. Gram's staining can differentiate the bacteria by the physical and chemical properties of the cell wall. A bacterial smear was colored by adding Crystal violet dye. After $1 \mathrm{~min}$, it was washed and air-dried, Next, Lugol's Iodine was added for $1 \mathrm{~min}$, then washed and airdried, followed by the $96 \%$ Ethanol addition for a few seconds. As the second dye solution, Safranin was added for $1 \mathrm{~min}$, then washed and air-dried. The Gram-positive bacteria were characterized as violet cells under the microscopy observation.

Motility. The bacterial colony was grown by stab inoculation on Sulfide Indole Motility Agar for 2x24 hours at $37^{\circ} \mathrm{C}$. The growth of motile bacteria was indicated with pellicle formation.

\section{Biochemical tests}

Catalase test. A catalase-positive bacteria produced oxygen bubbles after the addition of 2 drops $\mathrm{H}_{2} \mathrm{O}_{2}$ reagent on the bacterial smear.

Oxidase test. A single colony was smeared (then was covered with a paper) on a glass slide. Next, 3 drops of reagent (tetramethyl-D-phenylenediamine dihydrochloride) were added on the bacterial smear. The color changes into maroon blue were indicated a positive result.

Indole test. The bacterial colony was cultured in Tryptone Broth medium at $37^{\circ} \mathrm{C}$ for $2 \times 24$ hours. The formation of red-colored compound on the medium after the addition of Kovac's reagent was indicated a positive result.

Methyl Red-Voges Proskauer test. The Bifidobacteria isolates were cultured in Methyl Red \& Voges Proskauer medium at $37^{\circ} \mathrm{C}$ for 48 hours. For Methyl Red: A total of 5 drops of Methyl-Red reagent were added. For Voges Proskauer: A total of 5 drops of $40 \% \mathrm{KOH}$ and next $\alpha$ - naphthol reagents were added. After 5 minutes, a pinkcolor development was indicated a positive result.

\section{The $\mathrm{pH}$ ranges test}

The bacterial colony was cultured in the MRSB medium ( $\mathrm{pH} \mathrm{4,7,9).} \mathrm{A} \mathrm{positive} \mathrm{result} \mathrm{was} \mathrm{indicated} \mathrm{by} \mathrm{the}$ medium turbidity after $2 \times 24$ hours of incubation at $37^{\circ} \mathrm{C}$, anaerobically.

\section{Carbon source test}

The bacterial colony was cultured in mineral medium containing some sugar types: arabinose, fructose, galactose, glucose, glyculose, maltose, mannose, lactose, raffinose, ribulose, and sucrose, then incubated at $37^{\circ} \mathrm{C}$ for $2 \times 24$ hours, anaerobically. A positive result was indicated by the turbidity of the growth medium.

\section{Resistance test against lysozyme}

The MRSA medium was supplemented with egg whites as a source of lysozyme $\left(200 \mu \mathrm{g} \cdot \mathrm{mL}^{-1}\right)$. One milliliter of Bifidobacteria isolate was surface-plate grown on MRSA medium containing lysozyme, then incubated at $37^{\circ} \mathrm{C}$ for $2 \times 24$ hours, anaerobically. The growing colonies expressed their resistance to lysozyme $\left(200 \mu \mathrm{g} \cdot \mathrm{mL}^{-1}\right)$.

\section{Antimicrobial activity against pathogenic microorganisms}

A $3 \mathrm{~mL}$ of $E$. coli and $C$. albicans culture were added into $100 \mathrm{~mL}$ of Nutrient Broth (Merck) medium, then was incubated with shaking (incubator S1-600) at $150 \mathrm{rpm}$ for 8 hours. Bifidobacteria isolate was grown on MRSB medium and incubated at $37^{\circ} \mathrm{C}$ for 18 hours anaerobically, then, were centrifuged (Thermo Scientific) for $10 \mathrm{~min}$ at 13,000 $\mathrm{rpm}$. The inhibition activity of supernatant was further tested against $E$. coli and $C$. albicans, referred to as the previous study by Hendrati et al. (2017).

\section{Exopolysaccharide production}

A $0.75 \mathrm{~mL}$ of Bifidobacteria isolate was inoculated in $25 \mathrm{~mL}$ of MRSB medium, then was incubated at $37^{\circ} \mathrm{C}$ for $2 \times 24$ hours, anaerobically. Bacterial cell breakdown was done by cold centrifugation. A $10 \mathrm{~mL}$ of bacterial culture was transferred into micro-centrifuge tubes, then was centrifuged for $10 \mathrm{~min}$ at $10,000 \mathrm{rpm}, 4^{\circ} \mathrm{C}$. A $96 \%$ ethanol was added $(200 \%, \mathrm{v} / \mathrm{v})$ to the supernatant, then was stored overnight at $4^{\circ} \mathrm{C}$. Next, the supernatant was centrifuged for $25 \mathrm{~min}$ at $4,000 \mathrm{rpm}, 4^{\circ} \mathrm{C}$. The pellets were dried at $100^{\circ} \mathrm{C}$. The dry weight of the pellets was weighed as the exopolysaccharide weight in mg. $\mathrm{L}^{-1}$.

\section{RESULTS AND DISCUSSION}

\section{Isolation, Characterization, and Identification}

Twenty-two isolates were randomly picked up from the highest dilution-plates (six different plates) that appeared as white and round colonies on MRSA medium were considered as Bifidobacteria (Figure 1). The morphology of the bacterial colonies included the following characteristics: pinpoints, small and medium-size, roundshaped, milky-white, shiny surface, raised elevation, and 
flat edges (Table 1). Bifidobacterial colonies have morphological characteristics of milky white or near creamy colonies, in the form of round colonies, and wool edges with a diameter of 0.1-0.5 mm (Hadadji et al. 2005).

The Bifidobacterium-type isolates were further analyzed for their characterization and identification. Conventional identification and classification of Bifidobacterium species have been based on phenotypic and biochemical characteristics, such as cell morphology and sugar fermentation patterns. Manual characterization referred to Bergey's Determinative Bacteriology and Cowan \& Steel's Manual for the Identification of Medical Bacteria. Bifidobacteria have several key characteristics that can be used as references in determining the genus or species, such as Gram-positive, palisade shaped cell, nonmotile, and catalase-negative (Garrity et al., 2005; Okamoto et al., 2008; Zinedine \& Faid, 2007). All Bifidobacterium-type isolates were confirmed as Grampositive, rod-shaped, and non-motile (Table 1). They did not undergo decolorization during the Gram's staining process; therefore, they stay colored crystal violet. They did not perform a spreading pellicle formation; therefore, it was categorized as non-motile bacteria. These characterizations of Bifidobacterium-type isolates were also described by Hendrati et al. (2017).

The previous study of Hadadji et al. (2005) found that Bifidobacteria are categorized as catalase-negative. The catalase enzymes produced by the bacteria mediate the breakdown of $\mathrm{H}_{2} \mathrm{O}_{2}$ into $\mathrm{O}_{2}$ bubbles and water. The tested Bifidobacteria showed a positive result on the oxidase test, expressed by the maroon blue color formation. This positive result was also found by Lindawati and Suardana (2016). The Bifidobacteria did not form red-colored compounds on the surface of the Trypthon Broth medium. The color of the MR-VP broth medium was changed into pink or dark red. Then, it confirmed that the Bifidobacteria showed a positive result in Methyl Red, while negative in Indole and Voges-Proskauer tests. Since, Bifidobacteria do not grow in fermented mixed acid or butanediol fermentation (Venkatesn et al., 2012; Zinedine \& Faid, 2007). The Bifidobacteria were able to grow better at $\mathrm{pH} 7$ and 4 than $\mathrm{pH} 9$ medium (data not shown), which showed their tolerance to acidic conditions. Lindawati and Suardana (2016) found that Bifidobacteria are acid-tolerant bacteria.

The patterns of sugar-type fermentation provide a guideline for microbiological identification of Bifidobacteria which have been demonstrated to be strainspecific, rather than species-specific (Roy \& Ward, 1990). Limitations in using certain types of sugars can be used as a key to identify specific bacterial types. The sugar conversion is influenced by the enzymatic activity in bacterial cells. Not all bacteria can use all types of sugars as carbon sources, due to limited enzyme activities (Lawson et al., 2020; Okamoto et al., 2008). Bifidobacteria are capable of utilizing glucose, galactose, lactose, maltose, fructose, and some other sugar type as carbon sources (Munoz-Quezada et al., 2013; Okamoto et al., 2008). Bifidobacteria are positive to most of the carbon sources test: arabinose, fructose, galactose, glucose, glyculose, maltose, mannose, lactose, raffinose, ribulose, and sucrose (Table 2, Figure 2). The patterns of sugar-type fermentation identified the isolates as B. catenulatum (27.27\%), B. minimum (27.27\%), B. indicum $(27.27 \%)$, B. dentium (4.54\%), B. asteroides (4.54\%), B. galicum (4.54\%), and B. coerinum $(4.54 \%)$ (Table 2$)$.

Table 1. Characterization of Bifidobacterium-type Isolates

\begin{tabular}{|c|c|c|c|c|c|c|c|c|c|c|}
\hline \multirow{2}{*}{ Isolates } & \multicolumn{7}{|c|}{ Colony characters } & \multicolumn{3}{|c|}{ Other characters } \\
\hline & Size & Shape & Color & Surface & Elevation & Edge & Motility & Gram & Catalase & Oxidase \\
\hline $\mathrm{Bb} 1 \mathrm{~A}$ & Pin point & Round & Milky-white & Shiny & Raised & Flat & - & + & - & + \\
\hline $\mathrm{Bb} 1 \mathrm{~B}$ & Pin point & Round & Milky-white & Shiny & Raised & Flat & - & + & - & + \\
\hline $\mathrm{Bb} 1 \mathrm{C}$ & Pin point & Round & Milky-white & Shiny & Raised & Flat & - & + & - & + \\
\hline $\mathrm{Bb} 1 \mathrm{D}$ & Medium & Round & Milky-white & Shiny & Raised & Flat & - & + & - & + \\
\hline $\mathrm{Bb} 1 \mathrm{E}$ & Medium & Round & Milky-white & Shiny & Raised & Flat & - & + & - & + \\
\hline $\mathrm{Bb} 1 \mathrm{~F}$ & Medium & Round & Milky-white & Shiny & Raised & Flat & - & + & - & + \\
\hline $\mathrm{Bb} 1 \mathrm{G}$ & Pin point & Round & Milky-white & Shiny & Raised & Flat & - & + & - & + \\
\hline $\mathrm{Bb} 1 \mathrm{H}$ & Medium & Round & Milky-white & Shiny & Raised & Flat & - & + & - & + \\
\hline $\mathrm{Bb} 1 \mathrm{I}$ & Medium & Round & Milky-white & Shiny & Raised & Flat & - & + & - & + \\
\hline $\mathrm{Bb} 2 \mathrm{~A}$ & Medium & Round & White & Shiny & Raised & Flat & - & + & - & + \\
\hline $\mathrm{Bb} 2 \mathrm{~B}$ & Medium & Round & Milky-white & Shiny & Raised & Flat & - & + & - & + \\
\hline $\mathrm{Bb} 2 \mathrm{C}$ & Small & Round & Milky-white & Shiny & Raised & Flat & - & + & - & + \\
\hline $\mathrm{Bb} 2 \mathrm{D}$ & Medium & Round & Milky-white & Shiny & Raised & Flat & - & + & - & + \\
\hline $\mathrm{Bb} 2 \mathrm{E}$ & Medium & Round & Milky-white & Shiny & Raised & Flat & - & + & - & + \\
\hline $\mathrm{Bb} 3 \mathrm{~B}$ & Medium & Round & White & Shiny & Raised & Flat & - & + & - & + \\
\hline $\mathrm{Bb} 3 \mathrm{C}$ & Small & Round & White & Shiny & Raised & Flat & - & + & - & + \\
\hline $\mathrm{Bb} 3 \mathrm{D}$ & Small & Round & White & Shiny & Raised & Flat & - & + & - & + \\
\hline $\mathrm{Bb} 3 \mathrm{E}$ & Medium & Round & White & Shiny & Raised & Flat & - & + & - & + \\
\hline $\mathrm{Bb} 3 \mathrm{~F}$ & Small & Round & White & Shiny & Raised & Flat & - & + & - & + \\
\hline $\mathrm{Bb} 3 \mathrm{G}$ & Medium & Round & White & Shiny & Raised & Flat & - & + & - & + \\
\hline $\mathrm{Bb} 3 \mathrm{H}$ & Small & Round & White & Shiny & Raised & Flat & - & + & - & + \\
\hline
\end{tabular}



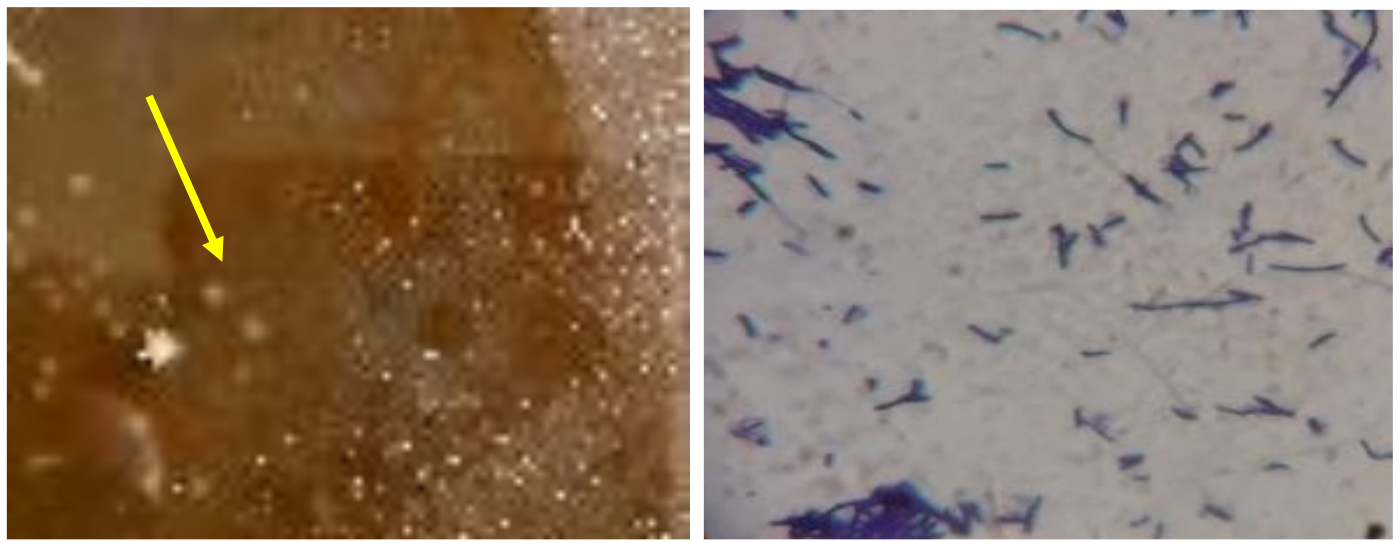

Figure 1. Colony of Bifidobacterium on MRSA (left) and microscopic cell morphology (right; 1000x magnification)

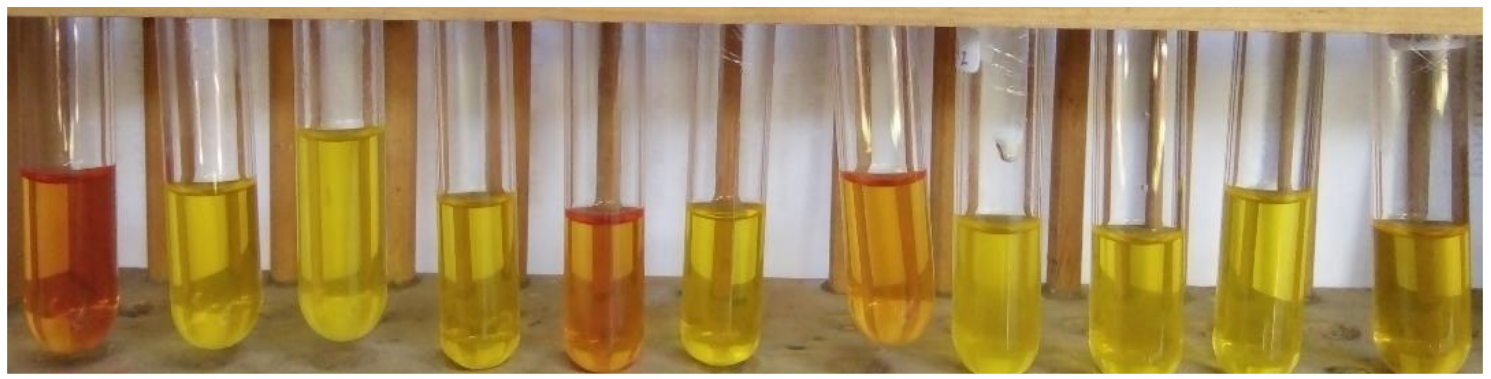

Figure 2. Carbon Source Test of Bifidobacterium Isolates

Table 2. Biochemical Test of the Isolated Bifidobacteria

\begin{tabular}{|c|c|c|c|c|c|c|c|c|c|c|c|c|c|c|c|c|}
\hline Isolates & Ara & Fru & Gal & Glu & Gli & Mal & Man & Lac & Raf & Rib & Suc & Ind & MR & VP & SC & Species \\
\hline $\mathrm{Bb} 1 \mathrm{~A}$ & + & + & + & + & + & + & + & + & + & + & + & - & + & - & + & B. catenulatum \\
\hline Bb1B & - & + & + & + & - & + & - & + & + & + & + & - & + & - & + & B. indicum \\
\hline $\mathrm{Bb} 1 \mathrm{C}$ & + & + & + & + & + & + & + & + & + & + & + & - & + & - & + & B. catenulatum \\
\hline Bb1D & + & + & + & + & + & + & + & + & + & + & + & - & + & - & + & B. catenulatum \\
\hline $\mathrm{Bb} 1 \mathrm{E}$ & - & + & - & + & - & + & - & - & - & + & - & - & + & - & + & B. indicum \\
\hline $\mathrm{Bb} 1 \mathrm{~F}$ & + & + & + & + & + & + & + & + & + & + & + & - & + & - & + & B. catenulatum \\
\hline $\mathrm{Bb} 1 \mathrm{G}$ & - & - & - & + & - & + & - & - & - & - & - & - & + & - & + & B. minimum \\
\hline $\mathrm{Bb} 1 \mathrm{H}$ & - & + & - & + & - & + & - & - & - & - & - & - & + & - & + & B. minimum \\
\hline Bb1I & + & + & + & + & + & + & + & + & + & + & + & - & + & - & + & B. catenulatum \\
\hline $\mathrm{Bb} 2 \mathrm{~A}$ & - & + & - & + & - & - & - & - & - & - & - & - & + & - & + & B. minimum \\
\hline $\mathrm{Bb} 2 \mathrm{~B}$ & - & + & + & + & - & + & - & + & + & + & + & - & + & - & + & B. indicum \\
\hline $\mathrm{Bb} 2 \mathrm{C}$ & + & + & - & + & - & - & - & - & - & - & - & - & + & - & + & B. galicum \\
\hline $\mathrm{Bb} 2 \mathrm{D}$ & + & + & + & + & + & + & + & + & + & + & - & - & + & - & + & B. minimum \\
\hline $\mathrm{Bb} 2 \mathrm{E}$ & + & + & + & + & + & + & + & + & - & - & - & - & + & - & + & B. dentium \\
\hline $\mathrm{Bb} 3 \mathrm{~A}$ & - & + & - & + & - & - & - & - & + & + & - & - & + & - & + & B. indicum \\
\hline $\mathrm{Bb} 3 \mathrm{~B}$ & - & + & - & + & - & + & - & - & - & - & - & - & + & - & + & B. minimum \\
\hline $\mathrm{Bb} 3 \mathrm{C}$ & - & + & - & + & - & + & + & - & - & - & - & - & + & - & + & B. minimum \\
\hline $\mathrm{Bb} 3 \mathrm{D}$ & - & - & - & + & - & - & - & - & - & - & - & - & + & - & + & B. asteroides \\
\hline $\mathrm{Bb} 3 \mathrm{E}$ & - & + & - & + & - & + & - & + & - & - & - & - & + & - & + & B. indicum \\
\hline $\mathrm{Bb} 3 \mathrm{~F}$ & - & + & - & + & - & + & - & - & - & - & - & - & + & - & + & B. indicum \\
\hline $\mathrm{Bb} 3 \mathrm{G}$ & + & + & + & + & + & + & + & + & + & + & + & - & + & - & + & B. catenulatum \\
\hline $\mathrm{Bb} 3 \mathrm{H}$ & - & + & - & - & - & + & - & - & - & - & - & - & + & - & + & B. coerinum \\
\hline
\end{tabular}

Note: Ara: Arabinose; Gal: Galactose; Fru: Fructose; Glu: Glucose; Gli: Glyculose; Mal: Maltose; Man: Mannose; Lac: Lactose; Raf: Raffinose; Rib: Ribulose; Suc: Sucrose; Ind: Indole; MR: Methyl Red; VP: Voges Proskauer, SC: Simmon's Citrate. 
Some studies have been identified around 32 species of Bifidobacterium, including 11 species from infant stool, such as B. breve, B. longum subsp. longum, B. bifidum, and B. longum subsp. infantis (Mariat et al., 2019; Narayanan \& Subramonian, 2015; Nomoto et al., 2017) as well as adult-associated species i.e. $B$. catenulatum and $B$. adolescentis (Duranti et al., 2017). The Bifidobacteria colonization is thought to begin during birth (Hendrati et al., 2017; Turroni et al., 2012). The microbial colonization of the infant digestive tract becomes more complex by the exposure of environmental microorganisms, breast-milk, and food consumption (Nomoto et al., 2017; Palmer et al., 2007; Turroni et al., 2012; Vaishampayan et al., 2010).

\section{Resistance to lysozyme}

Bifidobacteria as probiotic agents are recommended to be resistant to lysozyme. In some sources, lysozyme acts as an anti-microorganism since its enzymatic activity can disrupt the stability of the bacterial cell walls (Rockova et al., 2013; Sakurai et al., 2017). In this study, all Bifidobacteria isolates were qualified as probiotic which may be applied in the foods industry, because they were able to grow on lysozyme-supplemented MRSA medium (data not shown). This result indicated that the Bifidobacteria were resistant to $200 \mu \mathrm{g} \cdot \mathrm{mL}^{-1}$ lysozyme from egg whites. It might because the Bifidobacteria modify their peptidoglycan (Sakurai et al., 2017). Some studies found that Bifidobacteria are more resistant to 300 $\mu \mathrm{g} . \mathrm{mL}^{-1}$ lysozyme than Gram-negative bacteria (Rada et al., 2010). In some conditions, Bifidobacteria may tolerate up to $500 \mu \mathrm{g} \cdot \mathrm{mL}^{-1}$ lysozyme, although some cells have imperfect growth and die with varying percentages (Zinedine \& Faid, 2007). Probiotics are recommended to be resistant against lysozyme at $25-35 \mathrm{mg} . \mathrm{L}^{-1}$ and $50 \mathrm{mg} . \mathrm{L}^{-1}$ for the dairy industry and cheese products, respectively (Cardarelli et al., 2007; Guglielmonti et al., 2007).

\section{Antimicrobial Activity against Pathogenic Microorganisms}

Bifidobacteria play an important role in human immunity (Biasucci et al., 2008). As a probiotic agent,
Bifidobacteria fights against bacterial pathogens through some mechanisms, such as decline the $\mathrm{pH}$, compete for adhesion sites and nutrients, and produce antimicrobial agent e.g. hydrogen peroxide, organic acids and bacteriocins (Barzegari et al., 2020). Bacteriocins are secondary metabolites produced by LAB which act the same way to antibiotics (Pandey \& Malik, 2019). Some research studied the antimicrobial activity of bacteriocins against both Gram-negative and positive bacteria (Duranti et al., 2017; Martinz et al. 2013), and Candida infections (Kohler et al., 2012).

Figure 3 showed the different inhibition capacity of Bifidobacterium isolates against pathogenic E. coli and $C$. albicans. Some inhibition zones showed different appearances, ranging from clear to cloudy edged (Figure 4). A clear zone with cloudy edge indicates that some indicator bacteria remain alive. While, the clear edge indicates that the isolate has the ability of bactericidal metabolites which means it can kill the indicator bacterial cells (Pan et al., 2009). The largest antimicrobial activity against $E$. coli was shown by the $\mathrm{Bb} 3 \mathrm{~F}$ isolate, with an inhibition zone of $10.80 \mathrm{~mm}$, while the $\mathrm{Bb} 1 \mathrm{G}$ isolate showed the smallest inhibition of $6.0 \mathrm{~mm}$. According to Pan et al. (2009), the more than $6 \mathrm{~mm}$ clear zone express a strong inhibition activity, a 3-6 mm clear zone as moderate, while a 0-3 mm clear zone as weak inhibitory.

Candida spp. are common microbiota living in the human gastrointestinal tract and other mucosal surfaces (Vicariotto et al., 2012). For example, C. albicans is transmitted from mothers to infants during birth (Ward et al., 2017). Figure 3 showed that the largest inhibition activity of Bifidobacterium isolates against $C$. albicans was shown by $\mathrm{Bb} 1 \mathrm{~B}$ and $\mathrm{Bb} 3 \mathrm{~F}$ isolates with an inhibition zone of $9.70 \mathrm{~mm}$, while $\mathrm{Bb} 2 \mathrm{C}$ isolate showed the smallest inhibition zone of $7.0 \mathrm{~mm}$. To inhibit the $C$. albicans growth, Bifidobacteria disrupt the physical structure of cells membrane, reduce the development of cell filamentation (Cizeikiene et al., 2013; Kohler et al., 2012) and eradicate the Candida-biofilm formation (Barzegari et al., 2020; Ujaoney et al., 2014; Vicariotto et al., 2012).

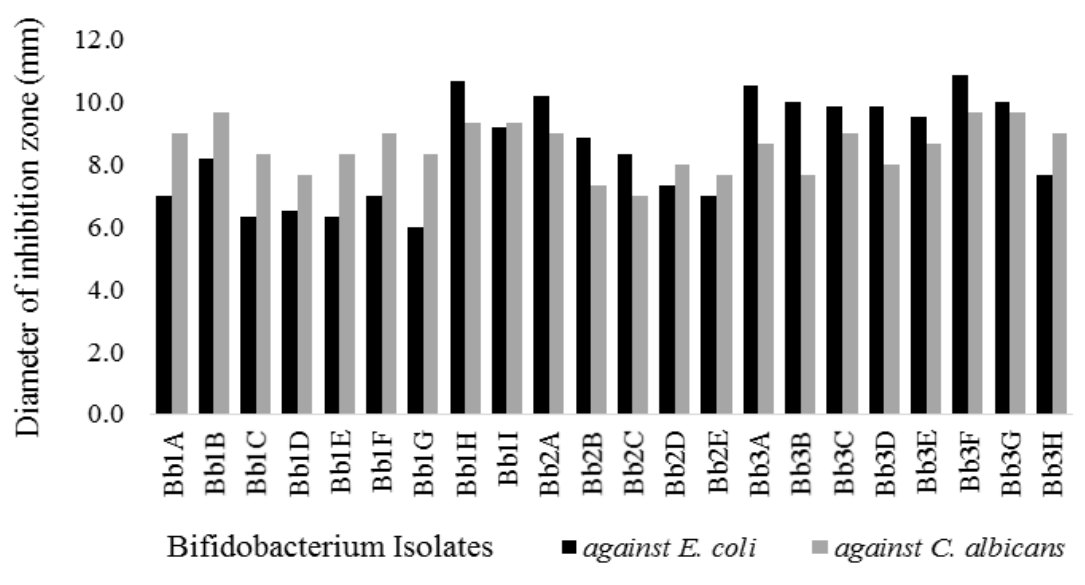

Figure 3. Inhibition Zone of Bifidobacteria Isolates against $C$. albicans and E. coli 


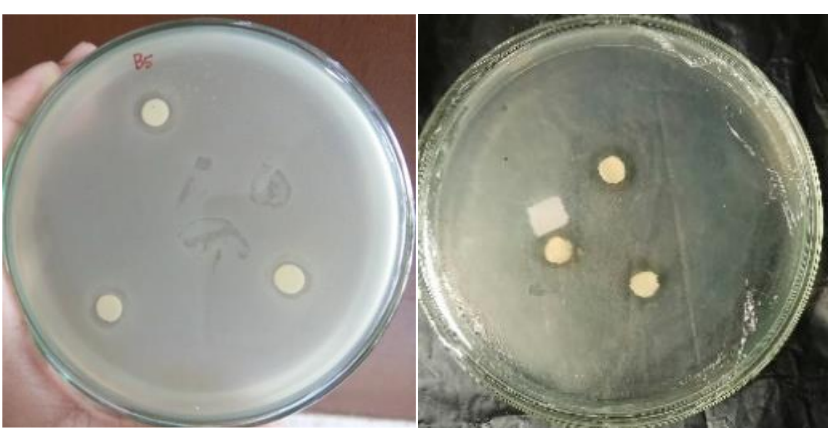

Figure 4. Inhibition zone of $\mathrm{Bb} 2 \mathrm{E}$ isolate against $E$. coli (left) and Bb1B isolate against $C$. albicans (right)

\section{Exopolysaccharide (EPS) production}

Exopolysaccharides (EPS) are carbohydrate polymers produced by bacteria in two forms, i.e. capsular and slime polysaccharide (Wu et al., 2010; Yan et al., 2017). Bacteria use the EPS to protect them from phagocytosis, stimulate immunomodulation activities, tolerate acidic conditions, and reduce pathogenic colonization in the gastrointestinal tract (Alp \& Aslim, 2010; Salazar et al., 2009). The bacteria group that produces EPS, e.g. Bifidobacteria spp. have the potential to be a probiotic agent. Figure 5 showed that EPS production by Bifidobacteria ranged from 5-74 mg. $\mathrm{L}^{-1}$. The highest yield of EPS was performed by Bb1A isolates, with $74 \mathrm{mg} . \mathrm{L}^{-1}$, while the lowest were Bb1F and Bb2C isolates i.e. $5 \mathrm{mg} . \mathrm{L}^{-1}$.

The medium composition e.g. carbon sources, temperature, $\mathrm{pH}$, and incubation time directly affects the EPS production (Behare et al., 2009; Prathima et al., 2014). Gayathiri et al. (2017) found the maximal EPS production at $24^{\text {th }}$ hour of incubation which decrease during the next growth stage. In the present study, MRSB medium containing glucose type sugar is used as the growth medium for EPS production. Meanwhile, Zubaidah et al. (2012) found that a good medium for EPS production is a medium containing lactose type sugar. In carbohydrate metabolism, lactose will be converted into galactose and glucose. The galactose acts as the precursor which increases the activity of related enzymes. It may also be correlated to Bifidobacterium ability in using lactose as the carbon source, since lactose is one of the most abundant components of human milk, besides human milk oligosaccharides, lipid, and protein (Pacheco et al., 2015). In breastfeed-infants gut, lactose and human milk oligosaccharides encourage the growth of Bifidobacterium (Lawson et al., 2020).

In conclusion, a total of 7 Bifidobacterium spp. were isolated from infant stool: B. catenulatum, B. minimum, $B$. indicum, B. dentium, B. asteroids, B. galicum, and $B$. coerinum. The $B$. indicum isolates (Bb3F and $\mathrm{Bb} 1 \mathrm{~B}$ ) had the greatest inhibition activity against $C$. albicans and $E$. coli with 9.70 and $10.80 \mathrm{~mm}$, respectively. Bifidobacterium isolates were resistant to lysozyme from egg whites up to $200 \mu \mathrm{g} \cdot \mathrm{mL}^{-1}$. The B. catenulatum (Bb1A isolate) had the highest yield of exopolysaccharide production with 74 mg. $\mathrm{L}^{-1}$. Three Bifidobacterium strains (Bb1B, Bb2A, and $\mathrm{Bb} 2 \mathrm{E})$ were considered potentially as probiotics.

\section{ACKNOWLEDGEMENTS}

Authors thank all who have helped in conducting this research and Universitas Jenderal Soedirman, Purwokerto, Banyumas, Indonesia for funding support.

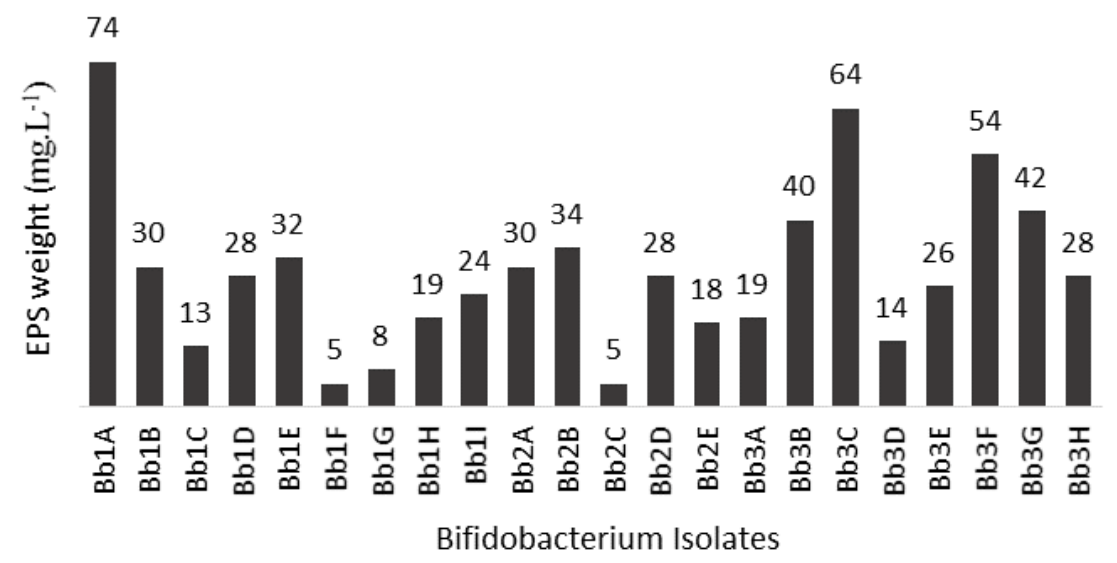

Figure 5. Exopolysaccharide Weight Produced by Bifidobacterium Isolates 


\section{REFERENCES}

Alp G, Aslim B. 2010. Relationship between the resistance to bile salts and low $\mathrm{pH}$ with exopolysaccharide (EPS) production of Bifidobacterium spp. isolated from infants feces and breast milk. Anaerobe 16: 101-105.

Attri S, Mahajan R, Goel G. 2018. Development and diversity of lactic acid-producing bacteria and bifidobacteria in healthy full-term Indian infants from Himachal Pradesh. Intest Res 16 (4): 529-536.

Barzegari A, Kheyrolahzadeh K, Khatibi SMH, Sharifi S, Memar MY, Vahed SZ. 2020. The battle of probiotics and their derivatives against biofilms. Infect Drug Resist 13: 659-672.

Behare PV, Singh R, Kumar M, Prajapati JB, Singh RP. 2009 Exopolysaccharides of lactic acid bacteria: A review. J Food Sci Technol 46 (1): 1-11.

Bermudez-Brito M, Plaza-Díaz J, Muñoz-Quezada S, Gómez-Llorente C, Gil A. 2012. Probiotic mechanisms of action. Ann Nutr Metab 61: 160-174.

Biasucci G, Benenati B, Morelli L, Boehm G. 2008. Cesarean delivery may affect the early biodiversity of intestinal bacteria. J Nutr 138 (9) 1796-1800

Cardarelli HR, Saad SM, Gibson GR, Vulevic J. 2007. Functional petitSuisse cheese: a measure of the prebiotic effect. Anaerobe 13: 200 207.

Cizeikiene D, Juodeikiene G, Paskevicius A, Bartkiene E. 2013 Antimicrobial activity of lactic acid bacteria against pathogenic and spoilage microorganisms isolated from food and their control in wheat bread. Food Cont 31: 539-545.

Duranti S, Lugli GA, Mancabelli L, Armanini F, Turroni F, James K, Ferreti P, Gorfer V, Ferrario C, Milani C, Mangifesta M, Anzalone R, Zolfo M, Viappiani A, Pasolli E, Bariletti I, Canto R, Clementi R, Cologna M, Crifo T, Cusumano G, Fedi S, Gottardi S, Innamorati C, Mase C, Postai D, Savio D, Soffiati M, Tateo S, Pedrotti A, Segata N, Van-Sinderen D, Ventura M. 2017. Maternal inheritance of bifidobacterial communities and bifidophages in infants through vertical transmission. Microbiome 5 (1): 66. DOI: 10.1186/s40168017-0282-6

Garrity GM, Brenner DJ, Kreig NR, Staley JT. 2005. Bergey's Manua Systematics Bacteriology. $2^{\text {nd }}$ ed. Vol. 2. The Proteobacteria. Springer, United States of America.

Gayathiri E, Bharathi B, Velu S, Siva N, Natarajan S, Prabavathi S, Selvadhas S. 2017. Isolation, identification, and optimization of exopolysaccharide producing lactic acid bacteria from raw dairy samples. Intl J Pharm Chem Res 3 (2): 202-211.

Guglielmonti DM, Marco MB, Golowczyc M, Reinheimer JA, Quiberoni AD. 2007. Probiotic potential of Lactobacillus delbrueckii strains and their phage resistant mutants. Int Dairy J 17: 916-925.

Hadadji M, Benama R., Saidi N, Henni E, Mebrouk K. 2005 Identification of cultivable bifidobacterium species isolated from breast-fed infants feces in West-Algeria. Afr J Biotechnol 4 (5): 422 430.

Hendrati PM, Kusharyati DF, Ryandini D, Oedjijono. 2017. Characterization of bifidobacteria from infant feces with differen modes of birth at Purwokerto, Indonesia. Biodiversitas 18 (3): 1265 1269.

Köhler GA, Assefa S, Reid, G. 2012. Probiotic interference of Lactobacillus rhamnosus GR-1 and Lactobacillus reuteri $\mathrm{RC}-14$ with the opportunistic fungal pathogen Candida albicans. Infect Dis Obstet Gynecol 2012: 636474. DOI: 10.1155/2012/636474.

Lawson MAE, O'Neill IJ, Kujawska M, Javvadi SG, Wijeyesekara A, Flegg Z, Chalklen L., Hall LJ. 2020. Breast milk-derived human milk oligosaccharides promote Bifidobacterium interactions within a single ecosystem. ISME J 14: 635-648.

Lindawati SA, Suardana IW. 2016. Isolasi dan identifikasi spesies bakteri asam laktat penghasil senyawa antimikrob asal kolon sapi Bali. J. Veteriner 17 (4): 576-6581.

Liu Z, Roy NC, Guo Y, Jia H, Ryan L, Samuelsson L, Thomas A, Plowman J, Clerens S, Day L. 2016. Human breast milk and infant formulas differentially modify the intestinal microbiota in human infants and host physiology in rats. J Nutr 146 (2): 191-199.

Mariat D, Firmesse O, Levenez F, Guimaraes VD, Sokol H, Dore J. 2019. The Firmicutes/Bacteroides ration of the human microbiota changes with age. BMC Microbiol 9 (1): 123. DOI: 10.1186/1471-2180-9123.
Martinz FAC, Eduardo MB, Attilio C, Paul DC, Ricardo PSO. 2013. Bacteriocin production by Bifidobacterium spp.: A Review. Biotechnol Adv 31: 482-488.

Munoz-Quezada S, Chenol E, Vieites JM, Genoves S, Maldonado J, Bermudez-Brito M, Gomez-Lorente C, Matencio E, Berna MJ, Romero F, Suarez A, Ramon D, Gil A. 2013. Isolation, identification and characterization of three novel probiotic strains (Lactobacillus paracasei CNCM I-4034, Bifidobacterium breve CNCM I-4035 and Lactobacillus rhamnosus CNCM I-4036) from the feces of exclusively breast-fed infants. Br J Nutr 109: S51-S62.

Narayanan R, Subramonian BS. 2015. Effect of prebiotics on bifidobacterial species isolated from infant feces. Indian $\mathrm{J}$ Tradit Know 14 (2): 285-289.

Nomoto R, Takano S, Tanaka K, Tsujikawa Y, Kusunoki H, Osawa R. 2017. Isolation and identification of Bifidobacterium species from feces of captive chimpanzees. Biosci Microb Food H 36 (3): 91-99.

Okamoto M, Benno Y, Leung KP, Maeda N. 2008. Bifidobacterium tsurumiense sp. Nov. from hamster dental plaque. Intl J Syst Evol Microbiol 58: 144-148.

Pacheco AR, Barile D, Underwood MA, Mills DA. 2015. The impact of milk glycobiome on the neonate gut microbiota. Annu Rev Anim Biosci 16 (3): 419-445.

Palmer C, Bik EM, Di-Giulio DB, Relman DA, Brown, PO. 2007. Development of the human infant intestinal microbiota. PLoS Biol 5: e177. DOI: 10.1371/journal.pbio.0050177.

Pan X, Chen F, Wu T, Tang H, Zhao Z. 2009. The acid, bile tolerance, and antimicrobial property of Lactobacillus acidophilus NIT. J. Food Cont 20 (6): 598-602.

Pandey N, Malik RK. 2019. Optimization of bacteriocin production from Lactobacillus gasseri NBL 18 through response surface methodology. Intl J Curr Microbiol App Sci 8 (3): 2000-2008.

Penders J, Thijs C, Vink C, Stelma FF, Snijders B, Kummeling I, Brandt PAVD, Stobberingh EE. 2006. Factors influencing the composition of the intestinal microbiota in early infancy. Pediatrics 118: 511-521.

Prathima PC, Lule VK, Tomar SK, Singh AK. 2014. Optimization of exopolysaccharide production by Lactococcus lactis NCDC 191 by response surface methodology. Intl J Curr Microbiol App Sci 3 (5): 835-854.

Rada V, Splichal I, Rockova S, Grmanova M, Vlkova E. 2010. Susceptibility of bifidobacteria to lysozyme as a possible selection criterion for probiotic bifidobacteria strains. Biotechnol Lett 32: 451455.

Ramakrishna B. 2013. Role of the gut microbiota in human nutrition and metabolism. J Gastroenterol Hepatol 28 (4): 9-17.

Ročková S, Rada V, Havlík J, Švejsti R, Vlková E, Bunešová V, Janda K, Profousová I. 2013. Lysozyme growth of bifidobacteria in mammalian milk. Czech J Anim Sci 58 (3): 99-105.

Roy D, Ward P. 1990. Evaluation of rapid methods for differentiation of Bifidobacterium species. J Appl Bacteriol 69: 738-749.

Sakurai T, Hashikura N, Minami J, Yamada A, Odamaki T, Xiao J. 2017. Tolerance mechanisms of human-residential bifidobacteria against lysozyme. Anaerobe 47: 104-110.

Salazar N, Prieto A, Leal JA, Mayo B, Bada-Gancedo JC, de Los ReyesGavilán CG, Ruas-Madiedo P. 2009. Production of exopolysaccharide by Lactobacillus and Bifidobacterium strains of human origin and metabolic activity of the producing bacteria in milk. J Dairy Sci 92: 4158-4168.

Sirilun S, Takahashi H, Boonyaritichaikji S, Chaiyasuti C, Lertruangpanya P, Koga Y, Mikami K. 2015. Impact of maternal bifidobacteria and the mode of delivery on Bifidobacterium microbiota in infants. Benef Microbes 6 (6): 767-774.

Subijanto, Reza. 2006. Konsep dasar penggunaan prebiotik - probiotik di dalam susu formula bayi dan susu formula khusus alergi. Fakultas Kesehatan, Universitas Airlangga, Surabaya. [Indonesian]

Turroni F, Peano C, Pass DA, Foroni E, Severgnini M, Claesson MJ, Kerr C, Hourihane J, Murray D, Fuligni F, Gueimonde M, Margolles A, De-Bellis G, O'Toole PW, van Sinderen D, Marchesi JR, Ventura M. 2012. Diversity of bifidobacteria within the infant gut microbiota. PLoS One 7: e36957. DOI: 10.1371/journal.pone.0036957.

Ujaoney S, Chandra J, Faddoul F. 2014. In vitro effect of over-the-counter probiotics on the ability of Candida albicans to form biofilm on denture strips. J Dent Hyg 88: 183-189.

Vaishampayan PA, Kuehl JV, Froula JL, Morgan JL, Ochman H. 2010. Comparative metagenomics and population dynamics of the gut microbiota in mother and infant. Genome Biol Evol 2: 53-66. 
Vicariotto F, Del PM, Mogna L, Mogna G. 2012. Effectiveness of the association of 2 probiotic strains formulated in a slow-release vaginal product, in women affected by vulvovaginal candidiasis: a pilot study. J Clin Gastroenterol 46: 73-80.

Ward TL, Knights D, Gale CA. 2017. Infant fungal communities: current knowledge and research opportunities. BMC Med 15 (1): 30. DOI: 10.1186/s12916-017-0802-z.

Wu MH, Pan TM, Wu YJ, Chang SJ, Chang SC, Hu CY. 2010 Exopolysaccharide activities from probiotic bifidobacterium: immunomodulatory effects (on J774A.1 macrophages) and antimicrobial properties. J Food Microbiol 144: 104-110.
Yan S, Guozhong Z, Xiaoming L, Jianxin Z, Hao Z, Wei C. 2017. Production of exopolysaccharide by Bifidobacterium longum isolated from elderly and infant feces and analysis of priming glycosyltransferase genes. RSC Adv 7: 31736-31744.

Zinedine A, Faid M. 2007. Isolation and characterization of strains of Bifidobacteria with probiotic properties in vitro. World J Dairy Food Sci 2 (1): 28-34.

Zubaidah E, Liasari Y, Saparianti E. 2012. Produksi eksopolisakarida oleh Lactobacillus plantarum B2 pada produk probiotik berbasis buah murbei. J Teknol Pertanian 9 (1): 58-60. [Indonesian] 